\title{
Association between hypertensive disorders of pregnancy and risk of autism in offspring: a systematic review and meta- analysis of observational studies
}

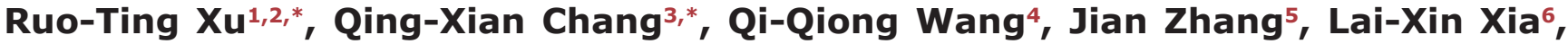 \\ Nanbert Zhong ${ }^{3,7,8}$, Yan-Hong $\mathbf{Y u}^{3}$, Mei Zhong ${ }^{3}$ and Qi-Tao Huang ${ }^{3}$ \\ ${ }^{1}$ Department of Neurology, Nanfang Hospital, Southern Medical University, Guangzhou, China \\ ${ }^{2}$ First School of Clinical Medicine, Southern Medical University, Guangzhou, China \\ ${ }^{3}$ Department of Obstetrics and Gynecology, Nanfang Hospital, Southern Medical University, Guangzhou, China \\ ${ }^{4}$ Department of Neonatology, Nanfang Hospital, Southern Medical University, Guangzhou, China \\ ${ }^{5}$ Department of Medical Genetics, School of Basic Medical Sciences, Southern Medical University, Guangzhou, China \\ ${ }^{6}$ Department of Developmental Biology, School of Basic Medical Sciences, Southern Medical University, Guangzhou, China \\ ${ }^{7}$ March of Dimes Global Network for Maternal and Infant Health, White Plains, NY, USA \\ ${ }^{8}$ Department of Human Genetics, New York State Institute for Basic Research in Developmental Disabilities, Staten Island, \\ NY, USA \\ "These authors contributed equally to this work
}

Correspondence to: Qi-Tao Huang, email: 15920454515@163.com

Mei Zhong, email: zhongm1960@163.com

Keywords: autism; childhood; pre-eclampsia; hypertensive disorders of pregnancy

Received: June 05, $2017 \quad$ Accepted: September 21, $2017 \quad$ Published: December 07, 2017

Copyright: $\mathrm{Xu}$ et al. This is an open-access article distributed under the terms of the Creative Commons Attribution License 3.0 (CC BY 3.0), which permits unrestricted use, distribution, and reproduction in any medium, provided the original author and source are credited.

\section{ABSTRACT}

Background: Autism spectrum disorder (ASD) is a common severe pervasive neurodevelopmental disorder of undetermined etiology. Environmental exposures, especially pregnancy complications, have been increasingly recognized as a potential risk factor for ASD. Our aim was to (1) systematically evaluate the association between hypertensive disorders of pregnancy (HDP) and the risk of ASD in offspring, (2) specifically draw a subgroup analysis of disease severity in patients with HDP to achieve more sufficient evidence on this issue.

Results: A total of $\mathbf{2 1}$ studies were identified with more than $\mathbf{6 . 5}$ million participants, including 31,027 ASD probands. A comparative meta-analysis established that offspring born premature to HDP were significantly associated with ASD than matched controls $(O R=1.42,95 \%$ CI: 1.34-1.50). Subgroup analysis of clinical classification include: (1) gestational hypertension, (2) pre-eclampsia, (3) chronic hypertension complicating pregnancy (CHP). The offspring of mothers with pre-eclampsia and CHP have slightly higher risk $(O R=1.43 ; O R=1.48$, respectively) of ASD than those of mothers with gestational hypertension ( $O R=1.37)$. In consistence with most previous researches, higher ASD prevalence was observed in male than female $(O R=1.38)$, indicating a potential role for gender in the pathophysiology of ASD.

Materials and Methods: We conducted a systematic literature search on PubMed, EMBASE, Web of Science, PsycINFO database and China National Knowledge Infrastructure up to Jun. 2017. Statistical analysis was performed using Stata 10.0.

Conclusions: This meta-analysis implies a possible link between HDP and the risk of ASD in offspring. However, further investigation should be conducted to confirm this conclusion, and intensive prenatal surveillance and early prediction for ASD is needed. 


\section{INTRODUCTION}

Autism spectrum disorders (ASD) is a neurodevelopmental syndrome characterized by various degrees of social impairment, deficits in language and communication, and repetitive patterns of behavior $[1,2]$, but the underlying mechanisms remain to be elucidated. The reported prevalence of ASD has increased dramatically over time to approximately 100/10,000 (1\%) today $[3,4]$, affecting the lives of 700,000 people and costing $£ 32$ billion each year in the UK [5]. The influence of prenatal exposures on development of ASD is gradually recognized, since substantial advances have been achieved in understanding the neurodevelopmental consequences of intrauterine challenges [6].

Hypertensive disorders of pregnancy (HDP) is a complex multisystem disorder, encompassing (1) gestational hypertension, (2) chronic hypertension complicating pregnancy (CHP), (3) pre-eclampsia and eclampsia [7], which can lead to severe maternal and fetal morbidity and even mortality [8]. Numerous studies have shown that fetal exposed to HDP had increased susceptibility to multiple neurodevelopmental disorders such as cognitive impairment [9], depression [10], schizophrenia [11], and even elevated lifetime risks for stroke [12]. Ratsep et al. [13] reported that offspring of pre-eclamptic pregnancies exhibited altered brain structural and vascular anatomy as enlarged brain regional volumes of the cerebellum was detected by magnetic resonance imaging, which shared similarities with those seen in ASD. It is demonstrated that pregnancies affected by pre-eclampsia are correlated with an exaggerated immune responses, creating a chronic and uncontrolled state of inflammation $[14,15]$. Epidemiological studies suggest that maternal infections (such as parasitic, bacterial and viral infection) [16] and autoimmune disorders (such as rheumatoid arthritis, asthma, systemic lupus erythematosis) [17], all of which lead to elevated immune responses, have been confirmed as independent risk factors for ASD [18].

Although a number of clinical studies [19-38] have been conducted to explore the undetermined association between HDP and ASD, the results of investigations were rather heterogeneous without collectively comparison. For instance, Walker et al. [26] observed that the children with ASD were twice as likely to have been exposed in utero to pre-eclampsia with controls, while Langridge et al. [36] failed to demonstrate statistically significant association between them. To determine whether all recent published epidemiologic studies, in combination, support an association between maternal HDP and the risk of ASD in offspring, we conducted a systematic review and meta-analysis of this issue. The aims of this study were to estimate the summary odds ratio for this association and have a comprehensive subgroup analysis to achieve more sufficient evidence of the association between disease severity and the risk of ASD.

\section{MATERIALS AND METHODS}

This meta-analysis was conducted following the guidance provided in the Cochrane Handbook and was reported according to the Meta-analysis of Observational Studies in Epidemiology (MOOSE) guidelines [39].

\section{Search strategy}

We performed a systematic electronic search in all available literature until Jun. 2017 on PubMed, EMBASE, Web of Science, PsycINFO database and China National Knowledge Infrastructure. We searched with the terms: "preeclampsia", "HDP", "hypertensive disorders of pregnancy", "hypertensive disorders in pregnancy", "hypertensive disorders complicating pregnancy", "pregnancy hypertension", "PIH", "pregnancy induced hypertension", "gestational hypertension", "gravid hypertension", "gravidic hypertension", "ASD", "autism spectrum disorder", "autism", "autistic disorder", "pervasive development disorders", "children", "childhood", "infantile". Searches were limited to human articles published in the English or Chinese. Two investigators inspected the titles and abstracts of citations and obtained the full texts. The search strategies are summarized in Figure 1. We also searched for additional relevant studies by browsing the bibliographies of the included trials and related reviews.

\section{Inclusion and exclusion criteria}

Studies were eligible if they: (i) were case-control studies, prospective studies, or RCTs; (ii) evaluated the association between HDP and ASD in offspring; (iii) presented relative risk (RR) or odds ratio (OR) estimates with $95 \%$ confidence intervals (CI) or necessary data for determination. Studies were excluded if they were (a) review articles, case reports, experimental studies, conference abstracts, animal studies or letters; (b) unpublished data; (c) lacked essential data for the pooled calculation. Two reviewers independently evaluated titles and abstracts of the identified articles and subsequently excluded those that were irrelevant.

\section{Data extraction}

A pair of investigators independently carried out the data extraction. Disagreements were resolved by discussion, with input from other investigators. Data extracted from each study included: the first author's last name, year of publication, study location, study design, characteristics of study population (length of follow-up, sample size), number of ASD participants with or without HDP, effect sizes of the associations, covariates adjusted for in the analysis; diagnostic criteria of HDP and scoring of Newcastle-Ottawa Quality Assessment Scale (NOS). 


\section{Quality evaluation}

Quality evaluation of each included study was performed utilizing the Newcastle-Ottawa Scale (NOS) [40]. The assessment consisted of three major categories: selection (four items, one star for each), comparability (one item, up to two stars) and exposure (three items, one star for each). A maximum of nine stars can be given to one study. A final score of seven stars or more was regarded as high quality.

\section{Statistical analysis}

Stata version 12 (Stata Corporation, USA) was used for statistical analyses. Pooled odds ratios (OR) with 95\% confidence intervals (CIs) between HDP and ASD were used to estimate effect sizes. The heterogeneity was assessed using both chi-squared test and $\mathrm{I}^{2}$ method [41]. When $P$ value for chi-squared test was less than 0.10 or $\mathrm{I}^{2}$ was more than $50 \%$, there was obvious heterogeneity among those included studies, and random-effect model was used to pool data. If there was no obvious heterogeneity among those included studies, a fixed-effect model was used to pool data. Subgroup analyses were stratified by clinical classification of HDP, maternal age, perinatal complications (preterm birth and premature rupture of membranes), maternal education, geographic area and gender of participants. Sensitivity analysis was performed by omitting one study by turns to test the changes of pooled ORs. Potential risk of publication bias was estimated by inspection of funnel plot. Publication bias was also assessed by Egger's test [42].

\section{RESULTS}

\section{Literature search and study characteristics}

Detailed search procedures are summarized in Figure 1. A total of 242 individual abstracts for potential studies were identified through literature search. 184 abstracts were excluded because they were irrelevant to the current meta-analysis. Of the 58 remaining clinical studies, 26 were further excluded for lacking of autism patients and 7 were letters, comments, editorials, or reviews, leaving 25 appropriate articles for full-text screening. We scrutinized the 25 articles and excluded 4 articles, including 2 exploring the association between HDP and schizophrenia and 2 showing outcomes as pregnancy complications. Thus, 21 studies with 6,527,652 unique participants met criteria for inclusion in the present metaanalysis. Among these 21 studies, 9 studies assessed the association between gestational hypertension and ASD, 11 assessed the relationship between pre-eclampsia and ASD, and the other 4 assessed the relationship between CHP and ASD. The detailed characteristics of these included studies are shown in Table 1.

\section{Quality assessment}

All 21 eligible studies were assessed for quality according to the NOS. The quality of them varied from 5 to 8 , with a mean of 6.57 (Table 2). All studies were included in the subsequent analysis.

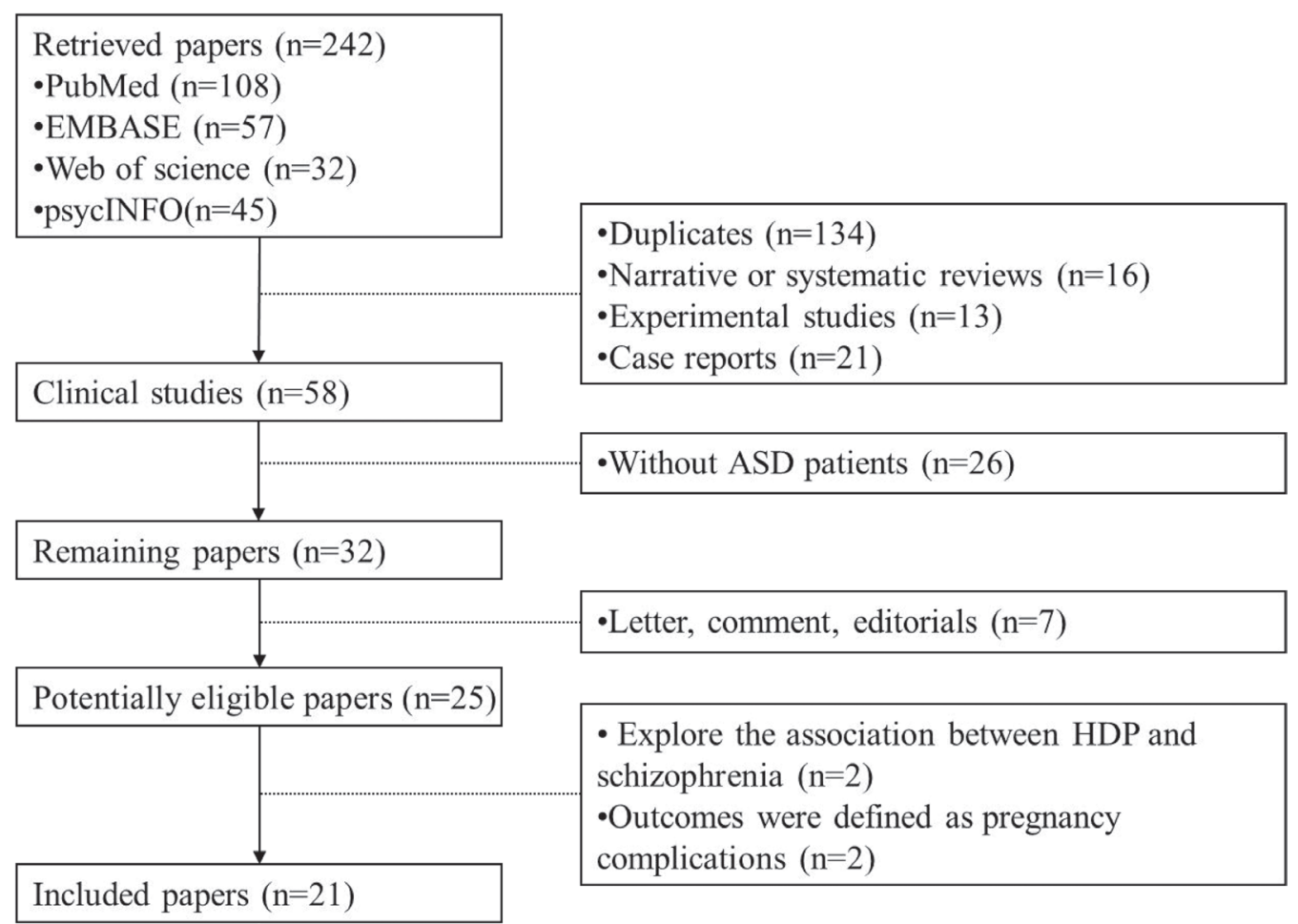

Figure 1: Flow diagram of the studies selection process. 
Table 1: Characteristics of all identified studies

\begin{tabular}{|c|c|c|c|c|c|c|c|c|c|c|c|}
\hline Reference & year & location & Design & Duration & $\begin{array}{c}\text { sample } \\
\text { size }\end{array}$ & $\begin{array}{c}\operatorname{HDP}(+) / \\
\operatorname{ASD}(+)\end{array}$ & HDP(+)/ASD(-) & OR $(95 \% \mathrm{CI})$ & $\begin{array}{l}\text { adjustment for } \\
\text { covariates }\end{array}$ & $\begin{array}{c}\text { Diagnostic } \\
\text { criteria }\end{array}$ & NOS \\
\hline Glasson EJ & 2004 & Australia & $\begin{array}{l}\text { Retrospective } \\
\text { cohort }\end{array}$ & 1980-1995 & 1778 & $33 / 465$ & $94 / 1313$ & $0.99(0.66-1.50)$ & $\begin{array}{l}\text { Gender, birth year, } \\
\text { maternal age, PROM }\end{array}$ & $\begin{array}{l}\text { ICD-9 } \\
\text { DSM }\end{array}$ & 7 \\
\hline Buchmayer S & 2009 & Sweden & Case-control & 1987-2002 & 7296 & $\begin{array}{c}\text { GH: } \\
\text { 21/1216 } \\
\text { PE: } 39 / 1216\end{array}$ & $\begin{array}{l}\text { GH: } 90 / 6080 \\
\text { PE: } 140 / 6080\end{array}$ & $\begin{array}{l}\text { GH: } 1.04(0.59-1.81) \\
\text { PE: } 1.64(1.08-2.49)\end{array}$ & $\begin{array}{l}\text { Maternal age, preterm } \\
\text { birth, gender, birth year, } \\
\text { delivery hospital }\end{array}$ & $\begin{array}{l}\text { ICD-9 } \\
\text { ICD-10 }\end{array}$ & 8 \\
\hline Matsuishi T & 1999 & Japan & $\begin{array}{l}\text { Prospective } \\
\text { cohort }\end{array}$ & 1983-1987 & 223 & $2 / 18$ & $27 / 205$ & NR & Maternal age, PROM & DSM-III-R & 8 \\
\hline Stein D & 2006 & Israel & Case-control & 1970-1998 & 358 & $\begin{array}{l}\text { GH: } 23 / 206 \\
\text { PE: } 11 / 206\end{array}$ & $\begin{array}{l}\text { GH: } 17 / 152 \\
\text { PE: } 18 / 152\end{array}$ & NR & $\begin{array}{c}\text { Gender, maternal } \\
\text { education, maternal age, } \\
\text { preterm birth, PROM }\end{array}$ & $\begin{array}{l}\text { ICD-VIII } \\
\text { DSM-III } \\
\text { DSM-IV }\end{array}$ & 5 \\
\hline Larsson HJ & 2005 & Denmark & Case-control & 1972-1999 & 9464 & $11 / 364$ & $181 / 9100$ & $1.54(0.83-2.86)$ & $\begin{array}{l}\text { Child age, gender, birth } \\
\text { year, preterm birth, } \\
\text { maternal education }\end{array}$ & $\begin{array}{l}\text { ICD-8 } \\
\text { ICD-10 }\end{array}$ & 7 \\
\hline Burstyn I & 2010 & Canada & Cohort & 1998-2004 & 216342 & $27 / 1122$ & $2747 / 215220$ & $1.49(1.00-2.23)$ & Maternal age, gender & ICD-9 & 7 \\
\hline Mann JR & 2010 & America & $\begin{array}{l}\text { Retrospective } \\
\text { Cohort }\end{array}$ & 1996-2002 & 87677 & $52 / 472$ & $5479 / 87205$ & NR & $\begin{array}{l}\text { Gender, maternal age } \\
\text { and education, preterm } \\
\text { birth }\end{array}$ & ICD-9 & 8 \\
\hline Walker CK & 2015 & America & Case-control & 2003-2011 & 867 & $\begin{array}{c}\text { CHP: } \\
17 / 510 \\
\text { Mild PE: } \\
\text { 23/408 } \\
\text { Severe PE: } \\
\text { 26/408 }\end{array}$ & $\begin{array}{c}\text { CHP: } 4 / 347 \\
\text { Mild PE: 9/277 } \\
\text { Severe PE: } \\
7 / 277\end{array}$ & NR & $\begin{array}{l}\text { Child age, gender, } \\
\text { geographic area, } \\
\text { maternal education }\end{array}$ & $\begin{array}{l}\text { ADI-R } \\
\text { ADOS }\end{array}$ & 5 \\
\hline Gillberg C & 1983 & Sweden & Case-control & $1962-1980$ & 50 & $12 / 25$ & $6 / 25$ & NR & $\begin{array}{c}\text { Gender; obestetric } \\
\text { department }\end{array}$ & NR & 8 \\
\hline Dodds L & 2011 & Canada & $\begin{array}{l}\text { Retrospective } \\
\text { cohort }\end{array}$ & 1990-2002 & 129733 & $106 / 924$ & $11730 / 128809$ & $1.24(1.02-1.52)$ & $\begin{array}{l}\text { Gender, maternal age, } \\
\text { preterm birth }\end{array}$ & $\begin{array}{l}\text { ICD-9 } \\
\text { ICD-10 }\end{array}$ & 7 \\
\hline $\begin{array}{c}\text { Mason- } \\
\text { Brothers A }\end{array}$ & 1990 & America & $\begin{array}{l}\text { Retrospective } \\
\text { Cohort }\end{array}$ & 1965-1984 & 285 & $17 / 225$ & $11 / 60$ & NR & $\begin{array}{l}\text { Gender, PROM, } \\
\text { maternal age }\end{array}$ & DSM-III & 5 \\
\hline Krakowiak P & 2012 & America & Case-control & 2003-2010 & 832 & $\begin{array}{c}\text { CHP: } \\
19 / 517 \\
\text { GH: } \\
148 / 517\end{array}$ & $\begin{array}{l}\text { CHP: } 4 / 315 \\
\text { GH: } 61 / 315\end{array}$ & NR & $\begin{array}{l}\text { Gender, maternal age } \\
\text { and education, ethnicity, } \\
\text { preterm birth }\end{array}$ & $\begin{array}{l}\text { ADI-R } \\
\text { ADOS }\end{array}$ & 7 \\
\hline Moore GS & 2012 & America & $\begin{array}{l}\text { Retrospective } \\
\text { cohort }\end{array}$ & 1991-2001 & 5979605 & $\begin{array}{c}\text { CHP: } \\
\text { 201/21717 } \\
\text { PE: } \\
1249 / 21717\end{array}$ & $\begin{array}{c}\text { CHP: } \\
\text { 38158/5957888 } \\
\text { PE: } \\
257401 / 5957888\end{array}$ & $\begin{array}{c}\text { CHP: } 1.45 \\
(1.26-1.67) \\
\text { PE: } 1.42(1.29-1.57) ;\end{array}$ & $\begin{array}{l}\text { Gender, maternal age, } \\
\text { ethnicity, birth order }\end{array}$ & ICD-9 & 7 \\
\hline $\begin{array}{c}\text { Korzeniewski } \\
\text { SJ }\end{array}$ & 2013 & America & Case-control & 1984-1987 & 177 & $5 / 12$ & $27 / 165$ & NR & $\begin{array}{l}\text { Gender, birth year, } \\
\text { birthweight, maternal } \\
\text { age and education, } \\
\text { preterm birth }\end{array}$ & NR & 6 \\
\hline Hadjkacem I & 2016 & Tunisia & Case-control & 2014-2014 & 101 & $5 / 50$ & $3 / 51$ & NR & $\begin{array}{l}\text { Gender, maternal age, } \\
\text { gender, preterm birth }\end{array}$ & DSM-V & 6 \\
\hline Bilder D & 2009 & America & Case-control & 1998-2002 & 13320 & $\begin{array}{c}\text { CHP: } 1 / 120 \\
\text { GH: } 7 / 120\end{array}$ & $\begin{array}{l}\text { CHP: } 63 / 13200 \\
\text { GH: } 524 / 13200\end{array}$ & $\begin{array}{c}\text { CHP: } 1.752 \\
(0.241-12.738) \\
\text { GH: } 1.466 \\
(0.695-3.231)\end{array}$ & Gender, birth year & $\begin{array}{l}\text { DSM-IV- } \\
\text { TR }\end{array}$ & 7 \\
\hline Lyall $\mathrm{K}$ & 2012 & America & $\begin{array}{l}\text { Prospective } \\
\text { cohort }\end{array}$ & 1989-2003 & 66445 & $111 / 793$ & $6700 / 65652$ & NR & $\begin{array}{l}\text { Ethnicity, marital } \\
\text { status,maternal age }\end{array}$ & NR & 5 \\
\hline Langridge AT & 2013 & Australia & $\begin{array}{c}\text { Retrospective } \\
\text { cohort }\end{array}$ & 1984-1999 & 5303 & $-/ 727$ & $-/ 4576$ & $1.25(0.97,1.61)$ & Gender & $\begin{array}{l}\text { DSM-IIIR } \\
\text { DSM-IV }\end{array}$ & 6 \\
\hline $\begin{array}{c}\text { Polo-Kantola } \\
\text { P }\end{array}$ & 2014 & Finland & Case-control & 1990-2005 & 5168 & $56 / 1036$ & $147 / 4132$ & $1.49(1.10-2.10)$ & $\begin{array}{l}\text { Gender, birth year, birth } \\
\text { place, maternal age }\end{array}$ & $\begin{array}{l}\text { ICD-9 } \\
\text { ICD-10 }\end{array}$ & 7 \\
\hline Hultman CM & 2002 & Sweden & Case-control & 1987-1994 & 2448 & $24 / 408$ & $76 / 2040$ & $1.6(0.90-2.90)$ & $\begin{array}{l}\text { Gender, birth year, } \\
\text { and delivery hospital, } \\
\text { maternal age, preterm } \\
\text { birth }\end{array}$ & ICD-9 & 7 \\
\hline Say GN & 2015 & Turkey & Case-control & 2015-2015 & 180 & $14 / 100$ & $6 / 80$ & NR & Age, gender & DSM-IV & 5 \\
\hline
\end{tabular}

OR, odds ratio; NR, not referred; ICD, International Classification of Diseases; DSM, Diagnostic and Statistical Manual; ADI-R, Autism Diagnostic Interview-Revised; ADOS, Autism Diagnostic Observation Schedule; NOS, Newcastle-Ottawa Quality Assessment Scale; GH: Gestational hypertension; PE: Pre-eclampsia; CHP: Chronic hypertension complicating pregnancy; PROM: Premature rupture of membranes

\section{Association of HDP with ASD in offspring}

After summarizing estimates from all available studies, there was a significant association between HDP and incidence of ASD (OR $=1.42,95 \%$ CI: $1.34-1.50)$ (Figure 2), without obvious heterogeneity $\left(I^{2}=39.9 \%\right.$, $P=0.016)$.

\section{Subgroup analysis}

Significant associations were detected in almost all strata of subgroup analyses according to clinical classification of HDP, maternal age, perinatal complications (preterm birth and premature rupture of membranes), maternal education, geographic area and 
gender of participants. Results of subgroup meta-analyses are summarized in Table 3.

\section{Analysis of sensitivity and publication bias}

Sensitivity analysis performed by omitting one study by turns showed all the pooled ORs were statistically significant (Figure 3 ). In addition, the funnel plot of this meta-analysis seemed to be symmetrical (Figure 4). And the Begg's test $(p=0.441)$ and Egger's test $(p=0.806)$ all suggested that there was not a possibility of publication biases that would influence the stability of the results.

\section{DISCUSSION}

Currently, accumulating studies were performed to evaluate the relationship between pregnant complications and child neurodevelopmental disorders based on populations. A previous meta-analysis [43] conducted by Gardener in 2009, suggested that there is insufficient evidence to implicate any one prenatal factor in autism etiology, and non-significant association $(\mathrm{OR}=1.01,95 \%$ CI: 0.80-1.27) has been observed between pre-eclampsia/ hypertension/edema and ASD. However, fourteen properly designed clinical trials were published from
2009 to 2017. Of these 14 studies, ten indicated a higher incidence of offspring ASD among HDP, while only 4 reported non-significance. Our meta-analysis update the previous review by covering the additional 9 years of publications, indicating that intrauterine exposure to HDP is associated with a $42 \%$ increase in the odds of ASD in the pooled estimate.

There is increasing evidence that maternal immune activation (MIA) is associated with a wide array of neurologic and psychiatric disorders [44, 45]. It is well documented that HDP, which is a state of MIA in itself, influences the fetal CNS development through inflammation. Subgroup meta-analyses defined by clinical classification of HDP revealed a slightly higher risk of pre-eclampsia $(\mathrm{OR}=1.43)$ or $\mathrm{CHP}$ group $(\mathrm{OR}=1.48)$ than gestational hypertension $(\mathrm{OR}=1.37)$, suggesting the incidence of ASD might be correlated with disease severity. Our results showed that the maternal age may not be a confound factor in the main analysis. The rate of preterm birth was higher in case group, indicating it was a potential confounder in the analysis of HDP and ASD, as most HDP pregnancy must be terminated through cesarean section before full-term. The subgroup analysis of premature rupture of membranes and maternal education didn't provide powerful evidence due to the limited

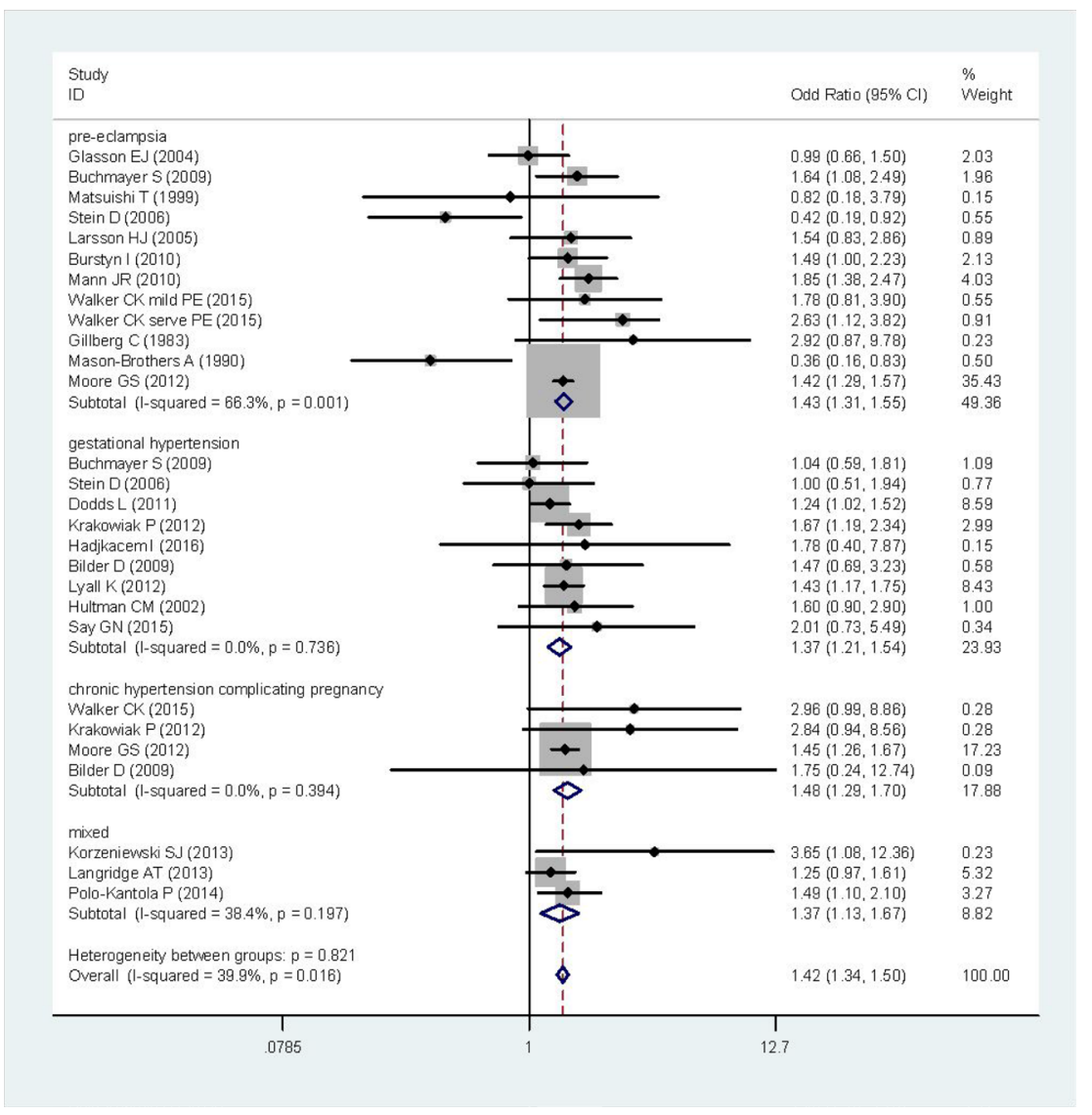

Figure 2: Forest plot of the correlation between HDP and ASD. The mixed group include pre-eclampsia, gestational hypertension and chronic hypertension complicating pregnancy. 
Table 2: Appraisal of methodological quality (Newcastle-Ottawa Scale) of the including studies

\begin{tabular}{|c|c|c|c|c|c|c|c|c|c|}
\hline Study & $\begin{array}{c}\text { Case-cohort } \\
\text { representative }\end{array}$ & $\begin{array}{c}\text { Selection of non- } \\
\text { exposed control }\end{array}$ & $\begin{array}{c}\text { Ascertainment } \\
\text { of exposure }\end{array}$ & $\begin{array}{c}\text { Outcome } \\
\text { negative at start }\end{array}$ & $\begin{array}{c}\text { Comparability } \\
\text { by design }\end{array}$ & $\begin{array}{c}\text { Comparability } \\
\text { by analysis }\end{array}$ & $\begin{array}{c}\text { Outcome } \\
\text { assessment }\end{array}$ & $\begin{array}{c}\text { Duration of } \\
\text { follow-up }\end{array}$ & Score \\
\hline Glasson EJ & $*$ & $*$ & ${ }^{*}$ & $*$ & $*$ & " & $*$ & $x$ & 7 \\
\hline Buchmayer S & * & * & * & * & * & * & * & * & 8 \\
\hline Matsuishi T & * & * & * & $*$ & * & * & * & * & 8 \\
\hline Stein D & * & * & * & $*$ & $x$ & * & $x$ & $x$ & 5 \\
\hline Larsson HJ & * & * & * & $x$ & * & $*$ & * & * & 7 \\
\hline Burstyn I & * & * & $\times$ & * & * & * & * & * & 7 \\
\hline Mann JR & * & * & * & * & * & * & * & * & 8 \\
\hline Walker CK & * & . & * & $x$ & * & * & $x$ & $\times$ & 5 \\
\hline Gillberg C & * & * & * & $*$ & * & * & * & * & 8 \\
\hline Dodds L & * & * & * & * & $x$ & * & * & * & 7 \\
\hline Mason-Brothers A & * & $x$ & * & $x$ & $*$ & * & $x$ & * & 5 \\
\hline Krakowiak P & * & * & $\times$ & $*$ & * & * & * & * & 7 \\
\hline Moore GS & * & $x$ & * & * & * & " & * & * & 7 \\
\hline Korzeniewski SJ & * & $x$ & * & $*$ & * & * & * & $\times$ & 6 \\
\hline Hadjkacem I & * & $x$ & $x$ & * & * & * & * & * & 6 \\
\hline Bilder D & * & * & * & $x$ & * & $*$ & * & * & 7 \\
\hline Lyall $\mathrm{K}$ & * & * & $x$ & * & * & $x$ & * & $\times$ & 5 \\
\hline Langridge AT & * & * & * & $*$ & $*$ & $\times$ & * & $\times$ & 6 \\
\hline Polo-Kantola P & * & * & $x$ & $*$ & * & * & * & * & 7 \\
\hline Hultman CM & * & * & $\times$ & * & * & * & * & * & 7 \\
\hline Say GN & * & * & * & $x$ & * & $x$ & * & $\times$ & 5 \\
\hline
\end{tabular}

"Indicates that a feature is present; $\times$, that a feature is absent. But for comparability by design this checklist awards a maximum of two stars $\left({ }^{* *}\right)$, one $\left({ }^{*}\right)$ or none if the feature is completely absence $(\times)$.

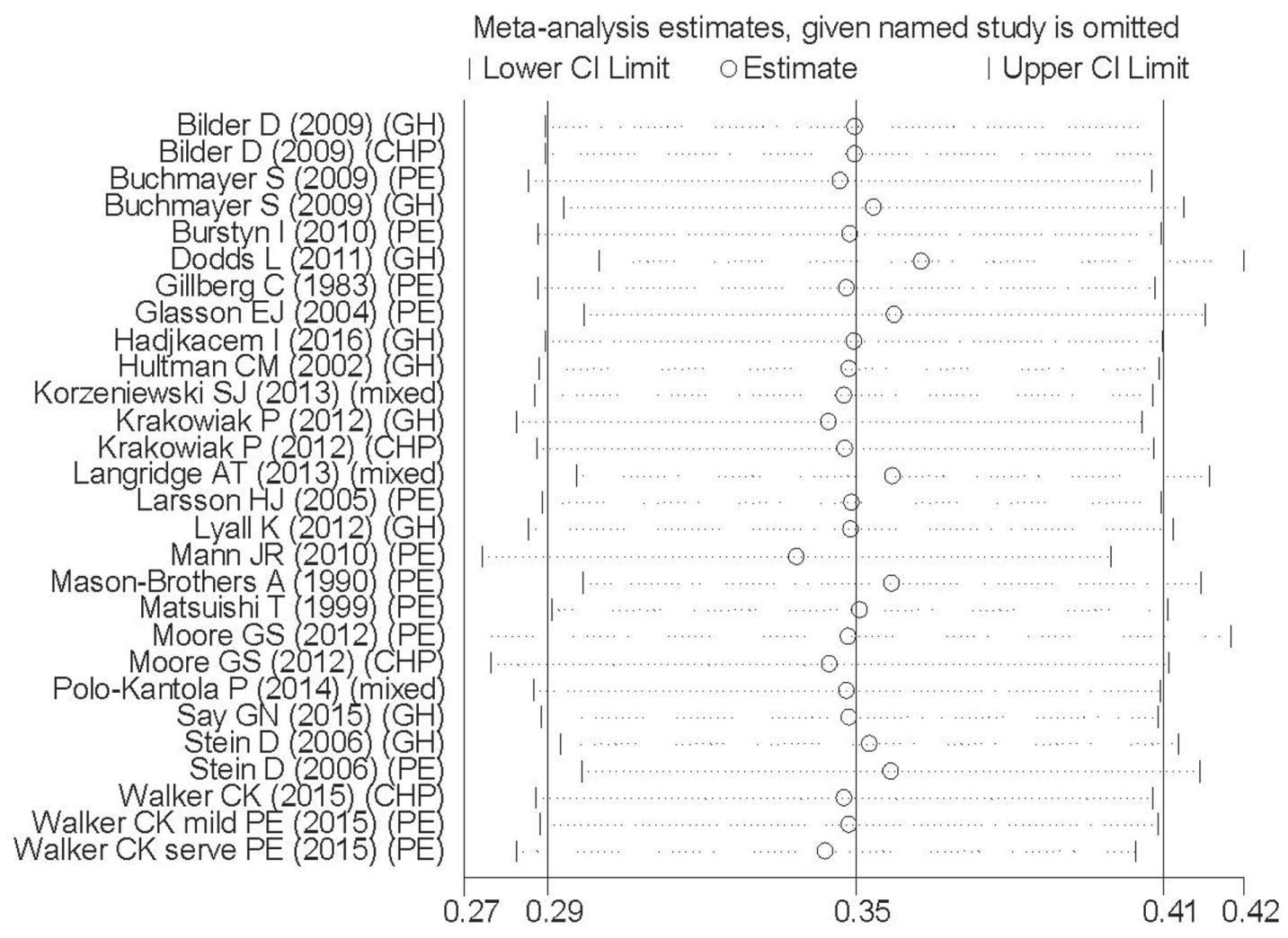

Figure 3: Sensitivity analysis of 21 studies included in this meta-analysis. GH: Gestational hypertension; PE: Pre-eclampsia; CHP: Chronic hypertension complicating pregnancy. 
Table 3: Subgroup analysis of the association between HDP and ASD

\begin{tabular}{|c|c|c|c|}
\hline & Studies & OR & $95 \% \mathrm{CI}$ \\
\hline \multicolumn{4}{|l|}{ Clinical classification } \\
\hline Gestational hypertension & 9 & 1.37 & $1.21-1.54$ \\
\hline Pre-eclampsia & 11 & 1.43 & $1.31-1.55$ \\
\hline Chronic hypertension complicating pregnancy & 4 & 1.48 & $1.29-1.70$ \\
\hline Mixed & 3 & 1.37 & $1.13-1.67$ \\
\hline \multicolumn{4}{|l|}{ Maternal age } \\
\hline Higher in the case group & 7 & 1.44 & $1.33-1.55$ \\
\hline Match between case and control & 7 & 1.29 & $1.11-1.50$ \\
\hline Lower in the control group & 2 & 1.42 & $1.16-1.73$ \\
\hline Not mentioned & 4 & 1.50 & $1.22-1.84$ \\
\hline \multicolumn{4}{|l|}{ Preterm birth } \\
\hline Higher rate in the case group & 7 & 1.41 & $1.22-1.63$ \\
\hline Match between case and control & 3 & 1.78 & $1.33-2.37$ \\
\hline Higher rate in the control group & 1 & 1 & $0.51-1.95$ \\
\hline Not mentioned & 10 & 1.41 & $1.32-1.51$ \\
\hline \multicolumn{4}{|l|}{ Premature rupture of membranes } \\
\hline Higher rate in the case group & 1 & 0.82 & $0.18-3.76$ \\
\hline Match between case and control & 3 & 0.92 & $0.66-1.28$ \\
\hline Higher rate in the control group & 1 & 1 & $0.51-1.95$ \\
\hline Not mentioned & 16 & 1.45 & $1.36-1.54$ \\
\hline \multicolumn{4}{|l|}{ Maternal education } \\
\hline Higher in the case group & 1 & 3.65 & $1.08-12.35$ \\
\hline Match between case and control & 3 & 1.90 & $1.57-2.31$ \\
\hline Higher in the control group & 2 & 1.26 & $0.80-1.99$ \\
\hline Not mentioned & 15 & 1.38 & $1.30-1.47$ \\
\hline \multicolumn{4}{|l|}{ Geographic area } \\
\hline Asia & 3 & 1.18 & $0.70-1.99$ \\
\hline America & 10 & 1.45 & $1.36-1.54$ \\
\hline Europe & 6 & 1.46 & $1.16-1.84$ \\
\hline Africa & 1 & 1.78 & $0.40-7.90$ \\
\hline Oceania & 2 & 1.17 & $0.94-1.45$ \\
\hline \multicolumn{4}{|l|}{ Gender of participants } \\
\hline Male/female higher in case group & 8 & 1.38 & $1.29-1.48$ \\
\hline Match & 9 & 1.68 & $1.42-1.99$ \\
\hline Male/female higher in control group & 0 & - & - \\
\hline Not mentioned & 4 & 1.44 & $1.19-1.74$ \\
\hline
\end{tabular}

The mixed group include pre-eclampsia, gestational hypertension and chronic hypertension complicating pregnancy.

statistical information. On the other hand, we found that males increased the risk of ASD than females (with an increase in odds by as much as $38 \%$ ), highlighting that sex-specific considerations will be crucial in exploring the underlying mechanism.

A meta-analysis [46] performed by Wang et al. in 2017 identified about 40 prenatal, perinatal, and postnatal factors which might increase the risk for ASD. However, these factors were examined individually. Therefore, it was still unclear that whether these factors are causal or play a secondary role in the development of autism. Moreover, although pre-eclampsia and gestational hypertension were identified as risk factors for autism in their study, these results were based on 3 or 5 studies, 
which had potential impact on the overall effect estimates. While in the present study, 9 and 11 studies were selected respectively to explore the association between gestational hypertension/pre-eclampsia and ASD, to draw a more reliable conclusion.

The strength of our meta-analysis, firstly, lies in its large sample size and comprehensive subgroup analysis, which allows a detailed examination of this association by stratifying the data according to clinical classification of HDP, maternal age, perinatal complications , maternal education, geographic area and gender of participants. Secondly, this study provides clinical evidence for the association between HDP and ASD in offspring, indicating that HDP may confer vulnerability to the fetal neurodevelopment. More clinical investigations are necessary to deeply investigate the mechanism, in the hope of illustrating the etiology of ASD and generating new therapies. Thirdly, the results from our sensitivity analyses suggest that our main results were credible to inclusion of studies and were not driven by a single study. There was insufficient statistical evidence of publication bias based on Egger's test. However, this meta-analysis also has some inherent limitations warranting discussion. First, blood pressure grade of HDP and drug treatment have been seldom mentioned in the included studies. Hence, the betweenstudy heterogeneity of blood pressure or treatment strategy could be potential confounders precluding rigorous evaluation. Second, the pooled estimates were originated from 12 case-control, 7 retrospective cohort and only 2 prospective studies. The NOS scores of included studies range from 5 to 8 , with a mean of 6.57 , indicating moderate quality according to NOS scale (moderate quality scored 4-6). There is a compelling need for larger-size, multi-center and higher-quality prospective studies with unified criteria to obtain more persuasive conclusions. Finally, our meta-analysis is not suitable for worldwide generalizability due to the geographic restriction of the selected studies, which were mostly comprised of participants from America or Europe. Future clinical investigations performed in other regions are highly needed.

In summary, the present comprehensive metaanalysis suggests that intrauterine exposure to hypertensive disorders during pregnancy might be a risk factor for ASD in offspring. Identifying the infants most at risk for ASD is crucial to allow for preventative interventions from birth [47]. One intriguing possibility is making use of the placenta, a readily accessible tissue at birth but normally discarded, to serve as a non-invasive method to predict abnormal fetal brain development. It would be worthwhile to explore the association between placental pathologies and ASD of offspring in the future, which may lead to targeted surveillance or prevention approaches, in order to decrease the risk and incidence of ASD.

\section{Begg's funnel plot with pseudo $95 \%$ confidence limits}

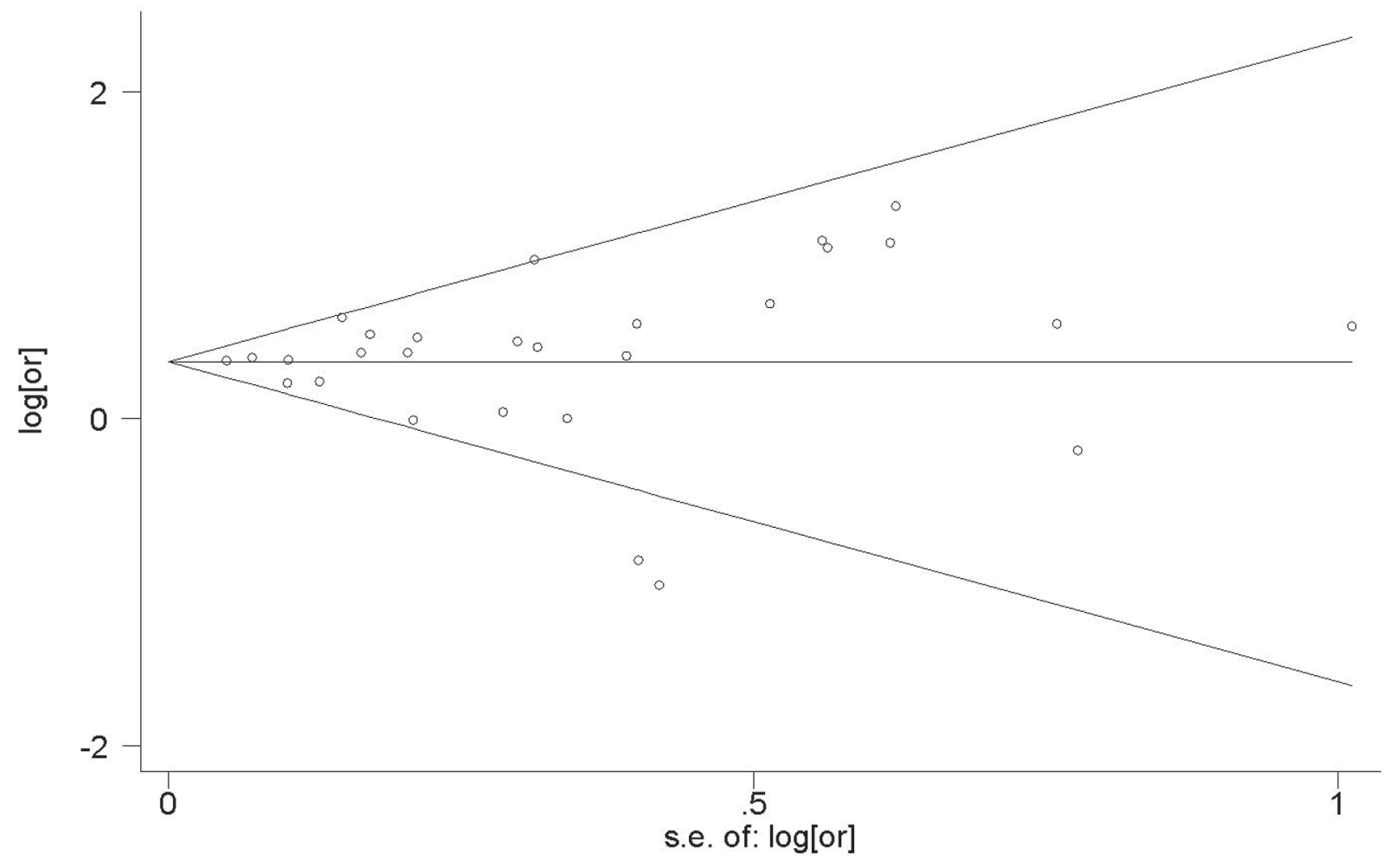

Figure 4: Funnel plot of 21 studies included in this meta-analysis. 


\section{Ethical approval}

The study was approved by the local Institutional Review Board.

\section{Author contributions}

Conceived and designed the experiments: QTH MZ YHY. Performed the experiments: JZ LXX NZ. Analyzed the data: RTX QXC QQW. Contributed reagents/materials/ analysis tools: JZ LXX NZ. Wrote the paper: RTX QTH.

\section{ACKNOWLEDGMENTS}

The authors thank Dr Oksana Shynlova from Lunenfeld-Tanenbaum Research Institute, Mount Sinai Hospital, Toronto, Ontario, Canada for reviewing and revising the manuscript.

\section{CONFLICTS OF INTEREST}

The authors have no competing interests to declare.

\section{FUNDING}

This work was supported by the National Natural Science Foundation of China (81401208, 81601175 , 81671466), Natural Science Foundation of Guangdong Province (2015A030310025, 2016A 03031040), the Guangdong Technologic Programme Foundation(2013B022000018), the Guangzhou Technologic Programme Foundation(2014Y2-00115), the Guangdong Medical Research Foundation (A2016539),National Undergraduate Training Program for Innovation and Entrepreneurship (201612121007) and the President Grant from Nanfang Hospital (2016B019, 2014B003).

\section{REFERENCES}

1. Moradi E, Khundrakpam B, Lewis JD, Evans AC, Tohka J. Predicting symptom severity in autism spectrum disorder based on cortical thickness measures in agglomerative data. Neuroimage. 2017; 144:128-141.

2. Lord C, Jones RM. Annual Research Review: Re-thinking the classification of autism spectrum disorders. J Child Psychol Psyc. 2012; 53:490-509.

3. Fombonne E. Epidemiology of Pervasive Developmental Disorders. Pediatr Res. 2009; 65:591-598.

4. Kogan MD, Blumberg SJ, Schieve LA, Boyle CA, Perrin JM, Ghandour RM, Singh GK, Strickland BB, Trevathan E, van Dyck PC. Prevalence of Parent-Reported Diagnosis of Autism Spectrum Disorder Among Children in the US, 2007. Pediatrics. 2009; 124:1395-1403.
5. McCall B. UK failing to meet the needs of people with autism. Lancet. 2017; 389:351-351.

6. Markham JA, Koenig JI. Prenatal stress: role in psychotic and depressive diseases. Psychopharmacology. 2011; 214:89-106

7. Brown MA, Lindheimer MD, de Swiet M, Van Assche A, Moutquin JM. The classification and diagnosis of the hypertensive disorders of pregnancy: statement from the International Society for the Study of Hypertension in Pregnancy (ISSHP). Hypertens Pregnancy. 2001; 20:Ix-xiv.

8. Ananth CV, Keyes KM, Wapner RJ. Pre-eclampsia rates in the United States, 1980-2010: age-period-cohort analysis. BMJ. 2013; 347.

9. Tuovinen S, Raikkonen K, Pesonen AK, Lahti M, Heinonen K, Wahlbeck K, Kajantie E, Osmond C, Barker DJ, Eriksson JG. Hypertensive disorders in pregnancy and risk of severe mental disorders in the offspring in adulthood: The Helsinki Birth Cohort Study. J Psychiatr Res. 2012; 46:303-310.

10. Tuovinen S, Raikkonen K, Kajantie E, Pesonen AK, Heinonen K, Osmond C, Barker DJ, Eriksson JG. Depressive symptoms in adulthood and intrauterine exposure to pre-eclampsia: the Helsinki Birth Cohort Study. BJOG. 2010; 117:1236-1242.

11. Eide MG, Moster D, Irgens LM, Reichborn-Kjennerud T, Stoltenberg C, Skjaerven R, Susser E, Abel K. Degree of fetal growth restriction associated with schizophrenia risk in a national cohort. Psychol Med. 2013; 43:2057-2066.

12. Kajantie E, Eriksson JG, Osmond C, Thornburg K, Barker DJ. Pre-Eclampsia Is Associated With Increased Risk of Stroke in the Adult Offspring The Helsinki Birth Cohort Study. Stroke. 2009; 40:1176-1180.

13. Ratsep MT, Paolozza A, Hickman AF, Maser B, Kay VR, Mohammad S, Pudwell J, Smith GN, Brien D, Stroman PW, Adams MA, Reynolds JN, Croy BA, et al. Brain Structural and Vascular Anatomy Is Altered in Offspring of PreEclamptic Pregnancies: A Pilot Study. Am J Neuroradiol. 2016; 37:939-945.

14. Santner-Nanan B, Peek MJ, Khanam R, Richarts L, Zhu EH, Fazekas de St Groth B, Nanan R. Systemic Increase in the Ratio between Foxp3(+) and IL-17-Producing CD4(+) $\mathrm{T}$ Cells in Healthy Pregnancy but Not in Preeclampsia. J Immunol. 2009; 183:7023-7030.

15. Wallace K, Richards S, Dhillon P, Weimer A, Edholm ES, Bengten E, Wilson M, Martin JN, LaMarca B. CD4(+) T-Helper Cells Stimulated in Response to Placental Ischemia Mediate Hypertension During Pregnancy. Hypertension. 2011; 57:949-U301.

16. Estes ML, McAllister AK. Immune mediators in the brain and peripheral tissues in autism spectrum disorder. Nat Rev Neurosci. 2015; 16:469-486.

17. Wojcik S, Bernatsky S, Platt R, Pineau C, Clarke A, Fombonne E, Berard A, Vinet E. Risk of Autism Spectrum Disorders in Children Born to Mothers with Rheumatoid 
Arthritis: A Systematic Literature Review. J Rheumatol. 2015; 42:1293-1294.

18. Knuesel I, Chicha L, Britschgi M, Schobel SA, Bodmer M, Hellings JA, Toovey S, Prinssen EP. Maternal immune activation and abnormal brain development across CNS disorders. Nat Rev Neurol. 2014; 10:643-660.

19. Glasson EJ, Bower C, Petterson B, de Klerk N, Chaney G, Hallmayer JF. Perinatal factors and the development of autism - A population study. Arch Gen Psychiat. 2004; 61:618-627.

20. Buchmayer S, Johansson S, Johansson A, Hultman CM, Sparen $\mathrm{P}$, Cnattingius S. Can association between preterm birth and autism be explained by maternal or neonatal morbidity? Pediatrics. 2009; 124:e817-825.

21. Matsuishi T, Yamashita Y, Ohtani Y, Ornitz E, Kuriya N, Murakami Y, Fukuda S, Hashimoto T, Yamashita F. Brief report: incidence of and risk factors for autistic disorder in neonatal intensive care unit survivors. Journal of autism and developmental disorders. 1999; 29:161-166.

22. Stein D, Weizman A, Ring A, Barak Y. Obstetric complications in individuals diagnosed with autism and in healthy controls. Compr Psychiat. 2006; 47:69-75.

23. Larsson HJ, Eaton WW, Madsen KM, Vestergaard M, Olesen AV, Agerbo E, Schendel D, Thorsen P, Mortensen PB. Risk factors for autism: Perinatal factors, parental psychiatric history, and socioeconomic status. Am J Epidemiol. 2005; 161:916-925.

24. Burstyn I, Sithole F, Zwaigenbaum L. Autism spectrum disorders, maternal characteristics and obstetric complications among singletons born in Alberta, Canada. Chronic diseases in Canada. 2010; 30:125-134.

25. Mann JR, McDermott S, Bao H, Hardin J, Gregg A. Preeclampsia, birth weight, and autism spectrum disorders. Journal of autism and developmental disorders. 2010; 40:548-554.

26. Walker CK, Krakowiak P, Baker A, Hansen RL, Ozonoff S, Hertz-Picciotto I. Preeclampsia, placental insufficiency, and autism spectrum disorder or developmental delay. JAMA pediatrics. 2015; 169:154-162.

27. Gillberg C, Gillberg IC. Infantile autism: a total population study of reduced optimality in the pre-, peri-, and neonatal period. Journal of autism and developmental disorders. 1983; 13:153-166.

28. Dodds L, Fell DB, Shea S, Armson BA, Allen AC, Bryson $\mathrm{S}$. The role of prenatal, obstetric and neonatal factors in the development of autism. Journal of autism and developmental disorders. 2011; 41:891-902.

29. Mason-Brothers A, Ritvo ER, Freeman BJ, Pingree C, Jenson WR, McMahon WM, Petersen PB, Jorde LB, Mo A, Ritvo A. The UCLA-University of Utah epidemiologic survey of autism: the etiologic role of rare diseases. The American journal of psychiatry. 1990; 147:1614-1621.

30. Krakowiak P, Walker CK, Bremer AA, Baker AS, Ozonoff S, Hansen RL, Hertz-Picciotto I. Maternal
Metabolic Conditions and Risk for Autism and Other Neurodevelopmental Disorders. Pediatrics. 2012; 129:e1121-e1128.

31. Moore GS, Kneitel AW, Walker CK, Gilbert WM, Xing GB. Autism risk in small- and large-for-gestational-age infants. American Journal of Obstetrics and Gynecology. 2012; 206.

32. Korzeniewski SJ, Pinto-Martin JA, Whitaker AH, Feldman JF, Lorenz JM, Levy SE, Movsas TZ, Pappas A, Paneth N. Association Between Transient Hypothyroxinaemia of Prematurity and Adult Autism Spectrum Disorder in a LowBirthweight Cohort: An Exploratory Study. Paediatr Perinat Ep. 2013; 27:182-187.

33. Hadjkacem I, Ayadi H, Turki M, Yaich S, Khemekhem K, Walha A, Cherif L, Moalla Y, Ghribi F. Prenatal, perinatal and postnatal factors associated with autism spectrum disorder. J Pediatr (Rio J). 2016; 92:595-601.

34. Grossi E, Veggo F, Narzisi A, Compare A, Muratori F. Pregnancy risk factors in autism: a pilot study with artificial neural networks. Pediatr Res. 2016; 79:339-347.

35. Lyall K, Pauls DL, Spiegelman D, Ascherio A, Santangelo SL. Pregnancy complications and obstetric suboptimality in association with autism spectrum disorders in children of the nurses' health study II. Autism Res. 2012; 5:21-30.

36. Langridge AT, Glasson EJ, Nassar N, Jacoby P, Pennell C, Hagan R, Bourke J, Leonard H, Stanley FJ. Maternal Conditions and Perinatal Characteristics Associated with Autism Spectrum Disorder and Intellectual Disability. Plos One. 2013; 8 .

37. Polo-Kantola P, Lampi KM, Hinkka-Yli-Salomaki S, Gissler M, Brown AS, Sourander A. Obstetric risk factors and autism spectrum disorders in Finland. The Journal of pediatrics. 2014; 164:358-365.

38. Hultman CM, Sparen P, Cnattingius S. Perinatal risk factors for infantile autism. Epidemiology (Cambridge, Mass). 2002; 13:417-423.

39. Stroup DF, Berlin JA, Morton SC, Olkin I, Williamson GD, Rennie D, Moher D, Becker BJ, Sipe TA, Thacker SB. Meta-analysis of observational studies in epidemiology: a proposal for reporting. Meta-analysis Of Observational Studies in Epidemiology (MOOSE) group. Jama. 2000; 283:2008-2012.

40. Cota GF, de Sousa MR, Fereguetti TO, Rabello A. Efficacy of anti-leishmania therapy in visceral leishmaniasis among HIV infected patients: a systematic review with indirect comparison. PLoS neglected tropical diseases. 2013; 7:e2195.

41. Higgins JP, Thompson SG, Deeks JJ, Altman DG. Measuring inconsistency in meta-analyses. BMJ (Clinical research ed). 2003; 327:557-560.

42. Egger M, Davey Smith G, Schneider M, Minder C. Bias in meta-analysis detected by a simple, graphical test. BMJ (Clinical research ed). 1997; 315:629-634.

43. Gardener H, Spiegelman D, Buka SL. Prenatal risk factors for autism: comprehensive meta-analysis. The British journal of psychiatry. 2009; 195:7-14. 
44. Simanek AM, Meier HC. Association Between Prenatal Exposure to Maternal Infection and Offspring Mood Disorders: A Review of the Literature. Current problems in pediatric and adolescent health care. 2015; 45:325-364.

45. Parboosing R, Bao Y, Shen L, Schaefer CA, Brown AS. Gestational influenza and bipolar disorder in adult offspring. Jama Psychiat. 2013; 70:677-685.
46. Wang CZ, Geng H, Liu WD, Zhang GQ. Prenatal, perinatal, and postnatal factors associated with autism A metaanalysis. Medicine. 2017; 96.

47. O'Keeffe GW, Kenny LC. Predicting infant neurodevelopmental outcomes using the placenta? Trends in molecular medicine. 2014; 20:303-305. 